\title{
Demand Elasticity Analysis of Islamic Banking Financing in Indonesia
}

\author{
Eka Fitriyanti ${ }^{1 *}$ \\ ${ }^{1}$ University of Bangka Belitung, Bangka Belitung, Indonesia
}

\begin{abstract}
This research aims to analyze the elasticity of demand for Islamic bank's financing in Indonesia. The variables observed in this study is inflation and income per capita. This research uses time series of data for the period 2004-2015, which is a secondary data. The Data is sourced from the central bank of Indonesia and Indonesian Central Bureau of Statistics, the models used in this study is a model of multiple regression equations and Analyzed using Ordinary Least Squares (OLS). Based on the estimates, the Research found that the inflation and income per capita significantly influence elasticity of demand for Islamic bank's financing in Indonesia. The elasticity of demand for Islamic bank's financing is inelastic to changes in price. This means that the demand Islamic bank's financing in Indonesia are not sensitive to changes in price. So, Islamic banks must be-able using other factors for growth Reviews their financing.
\end{abstract}

Keywords: Elasticity of Demand, Income per Capita, Inflation, Islamic bank's financing

\section{INTRODUCTION}

The price elasticity of demand for loans or financing has major implications for the macro economy, finance, and development. The continuity of the elasticity of demand affects the amount of substitution between inter-temporal in response to changes in the real interest rate, so the impact on a number of macroeconomic problems, including the composition and level of aggregate demand, the amount of interest tax, the burden of the national debt or social security funded and consumption cycle (Hall, 1988). On the financial side, the elasticity of consumer prices affect pricing decisions of companies where it is the market forces (Ausubel, 1991). In economic development, the demand elasticity explains that the importance of interest rate subsidies and strategies need to be designed to improve access to credit (Morduch, 2000).

Research conducted by Karlan \& Zinman (2005) who observed the elasticity of demand for consumer credit by presenting the parameter estimates are derived from a randomized trial. The experiment was conducted by microfinance lenders consumption in South Africa and identifies the demand curve, sloping downward in relation to the price. Show requests be very sensitive to price higher than normal interest rates. As well as finding the loan amount is more responsive to changes in the maturity of the loan from interest rate changes.

Attanasio, Goldberg, and Kyriazidou (2004), (hereinafter referred to as "AGK"), indicating that the elasticity of demand for credit in connection with the maturity of

* Corresponding author. Email address: ekafy1104@gmail.com 
the loan is an important parameter as well. These non-zero elasticity binding only in the presence of liquidity constraints; namely, liquidity constrained consumers must show sensitivity to the size of the loan payments and loan rates. AGK find widespread non elasticity of zero maturity in the market for car loans in the United States using survey data and a combination of structural exclusion restrictions and quasiexperimental

Bank gains mainly on providing loans (credit). About 66 percent of total bank assets in the form of loans, and credit generally produce more than half the bank's revenue. Credit is the obligation of individuals or companies who receive it, but it is an asset of the bank, because the credit can provide a profit for the bank (Mishkin, 2008).

If banks wanted to increase public saving, ceteris paribus, the interest rate will be raised so that the interest savings would be greater. Meanwhile, the fund distribution side, these interactions will affect the development of the banking credit to the public. If banks want to improve their credit expansion, ceteris paribus, lending rates will fall so that the interest for borrowing by the public increased (Pohan, 2008).

The interest rate on a conventional banking credit is opportunities costs in the formation of investment by the business sector, thus increasing the level of bank lending will reduce investment levels and then reduce economic growth. A decrease in the intensity of competition between banks will increase credit supply of banks or positively associated with the structure of bank credit. The increase in bank credit structure due to a decrease in the intensity of competition between banks will increase investment in real sector and then drive economic growth (Bank Indonesia Medan, 2007).

The economic crisis that hit Indonesia in 1997-1998, causing interest-based conventional banking crash. Many conventional banks to be liquidated because it is not able to cope with the economic crisis. However, Islamic banking remains strong stand and remain able to perform its intermediary function properly. In the period of bank restructuring, many conventional banks get help from the government, while the Islamic banking does not require government assistance (Noor, 2006).

Since the enactment of Law No. 21 of 2008 concerning Islamic banking, it provides greater opportunities for the development of Islamic banking in Indonesia because it has no clear legal basis will existence of Islamic banking in Indonesia. Islamic banking provides a wide range of banking products and services are diverse with more varied financial scheme, Islamic banking become a credible alternative banking system and can be enjoyed by all segments of society in Indonesia.

Operational's Islamic banks offer various types of products according to the needs of the people, the products of Islamic banks consist of al-wadiah, financing with profit sharing, buying and selling, al-wakalah, al-kafalah, alhawalah, and ar-rhan. Of all the products are the most widely used is financing with profit sharing and selling. In the Islamic banking system for the results on the use of funds by the borrower (either by the customer or the bank). The principle of profit sharing (profit sharing) which is a common characteristic and the basis for the overall operations of Islamic banks. Determining the amount of profit sharing portion between the two sides are determined according to mutual agreement, and should happen with their willingness ( $\mathrm{An}$ Tarodhin) on each side without any element of coercion (Antonio, 2001). 


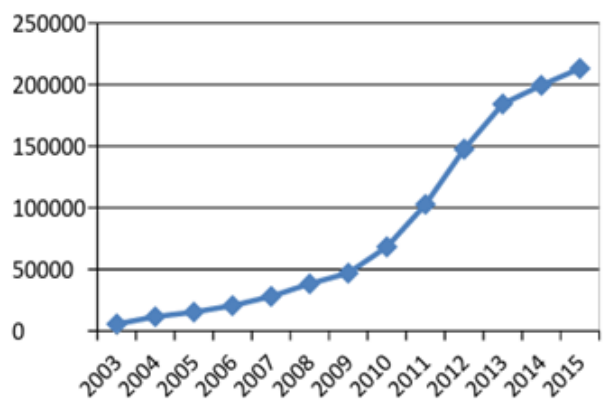

Figure 1

Source: Bank Indonesia, 2016

In the graph above shows that each year the demand for Islamic banking financing in Indonesia continues to increase. Financing request made customers in Islamic banks influenced the macro conditions of a country, one of which is the risk of decline in purchasing power due to inflation and a decline in average income communities. Based on the above problems, the formulation of the problem in this research is:

1. What form of financing on the elasticity of demand for Islamic Banking in Indonesia?

2. How is the effect of inflation on the elasticity of demand for financing in Islamic Banking in Indonesia?

3. How does the influence of the per capita income elasticity of demand for financing in Islamic Banking in Indonesia?

\section{LITERATURE STUDY}

\subsection{Demand Elasticity}

Price elasticity of demand (sometimes just called the price elasticity) measures how much the quantity demanded of a good changes when price changes. The exact definition of price elasticity is the percentage change in quantity demanded divided by the percentage change in price (Samuelson \& Nordhaus, 2003).

The goods will be very different from its price elasticity, or sensitivity to price changes. If the price elasticity of a high stuff, we say that the item has a request "elastic", which means that the quantity demanded are very sensitive to price changes. If the price elasticity of a product is low, then it is called as "inelastic" means that the quantity demanded is less sensitive to price changes. The time required for the person in response to price changes also play a role. In the short term demand for goods may be very inelastic. But in the long run you can adjust the behavior of the higher prices. The ability to adjust consumption patterns show that the elasticity of demand is generally higher in the long run than in the short term.

Calculate the coefficient of price elasticity numerically according to the following formula (Samuelson and Nordhaus, 2003):

Where:

$$
\text { Demand Elasticity }=\frac{\% \Delta \mathrm{Q}}{\% \Delta \mathrm{P}}
$$

$\% \Delta \mathrm{Q}$ : Percentage change in quantity 
$\% \Delta \mathrm{P}$ : Percentage change in price

As for the measurement of the elasticity of demand is expressed as follows (Samuelson \& Nordhaus, 2003):

1. $\mathrm{e}=0$, demand is perfectly inelastic, or demand with zero elasticity, is a condition in which the quantity demanded at all responsive to price changes.

2. $\mathrm{e}<1$, Where the percent change in price produces less than one percent change in the quantity demanded, then the goods that have inelastic price elasticity (demand is inelastic).

3. $\mathrm{e}=1$, demand is elastic unit (unitary), which occurs when one percent change in price produces one percent change in the quantity demanded.

4. e> 1, If the price changes one percent raises more than one percent change in quantity demanded, then stuff it has a price elasticity elastic (elastic demand).

5. $\mathrm{e}=\infty$, Demand is perfectly elastic, a small change in prices will lead to a huge change in the quantity demanded.

\subsection{Islamic Banking financing}

Basically the main function Islamic Bank is not much different from a conventional bank that is collecting funds from the public and then channel them back, or better known as the intermediary function. In practice, Islamic banks to channel funds it received in the form of financing, both venture capital financing as well as for consumption.

The notion of financing according to the various literature are as follows, According to Law No.10 of 1998 Financing is the provision of cash or the equivalent, based on agreements between the bank and other parties who require the parties financed to reimburse or the bill after a certain period of time in exchange or for the results.

According to Antonio (2001) financing is providing facilities for provision of funds to meet the needs of the parties which are deficit units. According to Muhammad (2002), financing is widely interpreted as funding is issued to support the planned investment by themselves or run by someone else.

Based on the understanding of the above, it can be concluded that the financing is providing facilities for provision of funds to support the planned investment is based on an agreement between the bank and other parties who require the financed party to return the money or the bill after a certain period of time in exchange or for the results.

According to Muhammad (2002), received the funds to the customer, the general Islamic financing products are divided into four categories, differentiated by the purpose of its use are:

1. Financing with the principles of the Sale and Purchase $\left(B a^{\prime} i\right)$

The principles of buying and selling conducted in connection with the transfer of ownership of goods or objects (Transfer of Property) the rate of profit is determined front and become part of the price of goods sold. Buying and selling can be distinguished based on the form of payment and delivery time which is as follows:
a. Murabahah
b. Financing Salam
c. Financing Istisnah

2. Financing with Lease Principle (Ijarah)

Ijarah transactions based on the movements of the benefits. So basically the same principle with the principle of Ijarah transactions, but the difference lies in the transaction object. When the object of the transaction is the sale and purchase of goods, the Ijarah transaction object is services. At the end of the lease, the bank can only sell 
goods that are leased to customers.

3. The principle of Sharing

Islamic finance products based on the principle of sharing is as follows:

a. Musharakah financing

b. Mudarabah

\subsection{Inflation}

Generally Understanding rising inflation is a general prices continuously. The price increase took place in a long time that happened in almost all goods and services, this is called inflation. If the price increases of one or two days only to one type of goods it can't be said to inflation. The opposite of inflation is deflation, deflation is a continuous decline in prices. According to K. Rimsky Judisseno said that inflation is one of the monetary events which showed a tendency to raise the price of goods in general that causes a decrease in the price of goods.

Definition of inflation according to Rahardja and Manurung, said that the definition of inflation is the increase in the prices of goods that are common and occur continuously. Definition of inflation according to Eachern, said that the definition of inflation is a constant rise in the average level of prices, if the price level fluctuation, this month and next month's ride down, each of the increase in employment is not as inflation. Understanding inflation and Sopeland according Weston, who said that the definition of inflation is an economic circumstances increased the price level high and can not be prevented or controlled anymore. Definition of inflation according to Sadano Sukirno, said in his macroeconomics that the definition of inflation is a process of increase of prices prevailing in an economy. Formula:

$$
\mathrm{IHK}=\frac{\sum \text { (Pit.Qio) }}{\sum \text { (Pio.Qio) }} \quad \mathrm{x} 100 \%
$$

Description:

Pit $=$ price of item $\mathrm{i}$ in period $\mathrm{t}$

Qit $=$ weight of item $\mathrm{i}$ in period $\mathrm{t}$

Pio $=$ the price of item $\mathrm{i}$ in the base period $\mathrm{o}$

Qio = weight of item $\mathrm{i}$ in the base period o

\subsection{Per Capita Income}

Per capita income of a country can be a benchmark to see levels of prosperity and progress of development of a country. Where the greater per capita income means more prosperous countries. Formula:

\subsection{Research Accomplished}

$$
\text { Income per capita }=\frac{\text { National Income in year of } X}{\text { Inhabitant Population in year of } X}
$$

Karlan \& Zinman (2005) examines the Consumer Credit Demand Elasticity. This study presents estimates of the parameters of a randomized trial. The experiment was conducted by microfinance lenders consumption in South Africa and identifies the demand curve, sloping downward in relation to the price. Requests be very sensitive to interest rates higher than the normal level. As well as finding the loan amount is much more responsive to changes in the maturity of the loan from interest rate changes.

Research conducted Insani Way, 2012 with the title of Credit Demand Analysis Consumer for Civil Servants On Banking in Makassar using analysis, multiple linear regression the result that the demand and use of consumer credit and the cost of 
obtaining revenue is affected credit. Loan interest and level of education does not significantly affect the credit demand.

Daughter of research Hutagalung \& Nasution, 2013, entitled Analysis Of Consumer Credit Demand Elasticity in North Sumatra by using multiple linear regression analysis, the result that the level of consumption SBK has a negative effect on the demand for consumer credit. The GDP per capita has a positive impact on demand for loans to consumer credit demand.

\subsection{Theoretical Framework}

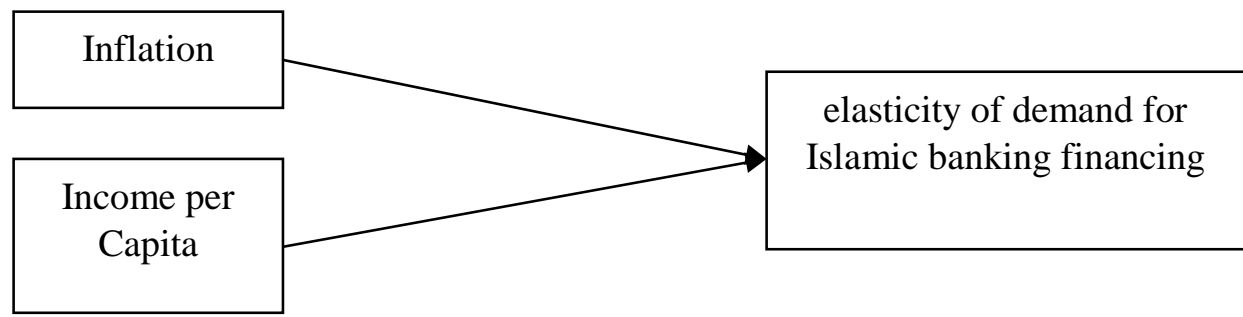

\subsection{Hypothesis}

1. Negative effects of inflation on the elasticity of demand for Islamic banking financing

2. Negative effect of income per capita to the elasticity of the Islamic banking financing

\section{RESEARCH METHODOLOGY}

\subsection{Scope of the Study}

The scope of this study was to determine how the elasticity of demand that is formed at the request of the financing of Islamic Banking in Indonesia, as well as how to influence variable inflation as macroeconomic variables and the national income per capita as a variable of economic development of the elasticity of demand for financing of Islamic Banking in Indonesia. The object of research is a kind of Islamic banking Islamic banks and Islamic business units.

\subsection{Data Types}

In conducting the study, the data used is secondary data with the data types used in the form of time series (time series) in the past 10 years (2004-2014), the quantitative is shaped figures.

\subsection{Data Collection Methods}

This study used data collection methods, namely the collection of Secondary data from Statistics Islamic Banking issued by Bank Indonesia and Indonesian Economic Report published by the Central Bureau of Statistics Indonesia as well as using the techniques of literature by collecting data from books, journals and research results, as well as the source of reading or writing material that is relevant to this study.

\subsection{Analysis Model}

Analysis model used in this research is multiple regression analysis as follows:

$$
\mathrm{Y}=\mathrm{f}(\mathrm{X} 1, \mathrm{X} 2)
$$

Systematically of these functions can be derived model of the following equation:

Where in:

$$
\mathrm{Y}=\alpha+\beta 1 \mathrm{X} 1+\beta 2 \mathrm{X} 2+\epsilon \mathrm{t}
$$

$\mathrm{Y}=$ Request Financing the Sharia Banking

$\mathrm{X} 1=$ Inflation

$\mathrm{X} 2=$ Growth National Income Per Capita 


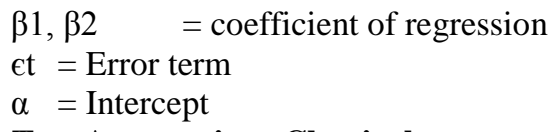

\subsection{Test Assumptions Classical}

Classic assumption test is the test data in thesis research to determine the condition of the data that is used in a research. A regression model was said to be exposed multicollinearity case of a perfect linear relationship between some or all of the independent variables of a regression model. To detect multicollinearity problems can be done in two ways, namely correlations between variables (correlation matrix) and using partial correlation.

To test whether normal or not confounding factors, it necessary is to test for normality using the Jarque-Bera test (JB test). Another way to see if data has normal distribution using this test JB is by looking at the probability.

Autocorrelation is a disruption in the form of correlation between the regression function disturbance factor (error term). There are several ways that can be used to detect the presence of autocorrelation, the graphical method, method h-statistics, test Durbin Watson (DW test) and test Lagrange Multiplier (LM test) in this study will test the Lagrange Multiplier (LM test) as the test autocorrelation.

\subsection{Compliance Test (Test Goodness of Fit)}

Conformance test (goodness of fit test) carried out by calculating the coefficient of determination $\left(\mathrm{R}^{2}\right)$, test F-statistics and t-test statistics.

1. Assessment of $R^{2}$ aims to look at the strength variation in the independent variables affect the dependent variable variation. $\mathrm{R}^{2}$ value is used between 0 and $1(0<2<1)$. The closer to 1 means that the more precise the regression line to predict the value of the dependent variable.

2. F-statistic test aims to determine the statistical significance of the regression coefficients simultaneously or together.

3. T-statistics test aims to determine the statistical significance of the partial regression coefficients.

\subsection{Operational Definition}

To facilitate understanding of the terms and variables used in this study, it should be given operational definition as follows:

1. Islamic banking financing Demand Elasticity is the percentage change in the number of Islamic banking financing demand due to the percentage change in the price of the financing of Islamic banking.

2. The growth of per capita income is a picture of the average income received by each resident in Indonesia expressed as a percentage.

3. Inflation is the increase in the prices of goods that are common and occurs continuously in Indonesia.

\section{RESULTS AND DISCUSSION}

\subsection{Descriptive Analysis}

1. Financing Development of Islamic Banking in Indonesia

Demand for Islamic banking financing in Indonesia in general continues to increase every year. It can be seen from the number of total finance portfolio of Islamic banking in Indonesia continues to increase as described in the following table: 
AFEBI Islamic Finance and Economic Review (AIFER)

Vol.02 No.01, June 2017

Table 1 Development of Islamic Banking Financing

\begin{tabular}{cccc}
\hline Year & $\begin{array}{c}\text { Equivalent Rate } \\
(\boldsymbol{\%})\end{array}$ & $\begin{array}{c}\text { Total Financing } \\
\text { (Billions rupiah) }\end{array}$ & $\begin{array}{c}\text { Demand } \\
\text { Elasticity }\end{array}$ \\
\hline 2003 & 14,28 & 5.530 & - \\
\hline 2004 & 11,06 & 11.490 & $-0,20922$ \\
\hline 2005 & 12,46 & 15.232 & 0,388677 \\
\hline 2006 & 11,42 & 20.445 & $-0,24388$ \\
\hline 2007 & 14,42 & 27.944 & 0,716208 \\
\hline 2008 & 15,02 & 38.195 & 0,113425 \\
\hline 2009 & 10,99 & 46.886 & $-1,17916$ \\
\hline 2010 & 10,82 & 68.181 & $-0,03406$ \\
\hline 2011 & 10,52 & 102.655 & $-0,05484$ \\
\hline 2012 & 18,34 & 147.505 & 1,701409 \\
\hline 2013 & 10,26 & 184.122 & $-1,77475$ \\
\hline 2014 & 12,67 & 199.330 & 2,843828 \\
\hline 2015 & 12,69 & 212.996 & 0,023024 \\
\hline
\end{tabular}

Source: Bank Indonesia, 2016

From the table above shows that the development of islamic banking financing from year to year increase was accompanied by a percentage equivalent rate fluctuation. The increase in Islamic banking financing continually show that Islamic banking is resistant to the crisis, it is evident from the above table of data showing that in 2008 the Islamic banking financing remains elevated even though at the time it is occurring shock the world financial system.

Changes percentage equivalent rate divided by the percentage change in the total financing may be formed elasticity of demand for Islamic banking financing. From the analysis of the elasticity of demand for Islamic banking financing in Indonesia, resulting that the financing of Islamic banking in Indonesia is included in the category of inelastic for most of the value of elasticity is less than 1 . The conditions under which a request is in the category inelastic means that when the price changes of $1 \%$ will give the effect of a change the amount of demand is less than $1 \%$ or less of the price change.

2. Inflation in Indonesia

Inflationist related to Indonesia's economy, because if the high inflation rate, it is certain that will affect economic growth, which the Indonesian economy will run very slowly. Inflation in Indonesia are like a chronic disease and it is rooted in history. The inflation rate in some of our neighboring countries like Malaysia and Cambodia are much lower. While the inflation rate in Indonesia is quite high. Entering in 2000 fairly restrained monetary stability with an inflation rate of $9.35 \%$ with a growth of $4.8 \%$. Inflation surged in 2005 approximately $17.11 \%$, the pressure will be adjusted price of fuel oil (BBM) is estimated to be the main factor of high inflation. High oil prices in international markets led the government to remove fuel subsidy. However, since 2005-2009, inflation was reduced to the single digits. From $17.11 \%$ in 2005 to $6.96 \%$ in 2009. Inflation tends to redistribute income upward so as to make jumbling balance toward economic justice. Moreover, inflation also raises price controls and subsidies on food staples for consumption. So, basically rising inflation makes people poorer and poorer, it is because when compared with the increase in a person's income per 
year, inflation is still higher.

3. Developments of income percapita in Indonesia

Speaking of income, then we can't be separated from the figure, the nominal money earned by a person/family in a certain period of time, could in a matter of a month, or per year. The per capita income can be defined as the amount of the average income of the population in a country. The per capita income for the results obtained from the national income of a country with a total population (population) of the country. The per capita income also reflects the amount of Gross Domestic Product (or commonly in short GDP) per capita.

The per capita income is usually used as a measure of the level of prosperity and the progress of development of a country, where the formula used is greater per capita income, it is considered that the more prosperous a country. Data declared by the Central Bureau of Statistics show that the per capita income growth tends to fluctuate. In times of crisis growth in per capita income has increased sharply in line with inflation that is very high.

\subsection{Classical Assumption Test}

Tests on the classical assumption will include multicollinearity, Autocorrelation, normality test, linearity and heteroscedasticity.

1. Multicolinearity

Test multicollinearity using VIF (Variance Inflation Factors).

Variance Inflation Factors

Table 2 Test Multicolinearity

Date: 04/29/17 Time: 22:17

Sample: 20042015

Included observations: 12

\begin{tabular}{llll}
\hline \hline Variable & $\begin{array}{l}\text { Coefficient } \\
\text { Variance }\end{array}$ & $\begin{array}{l}\text { Uncentered } \\
\text { VIF }\end{array}$ & $\begin{array}{l}\text { Centered } \\
\text { VIF }\end{array}$ \\
\hline \hline INFLASI & 0.000566 & 8.528840 & 1.005060 \\
PERKAPITA & 0.001864 & 89.16829 & 1.005060 \\
C & 0.358944 & 93.03198 & NA \\
\hline \hline
\end{tabular}

Source: Output of Eviews 9, 2017

Multicollinearity test results, can be seen in the above table VIF Centered column. VIF value for the variable inflation and per capita income are equally 1.005060. Because the VIF value of the two variables is no greater than 10 or 5 (a lot of books that requires no more than 10 , but there is also that requires no more than 5) it can be said does not happen multicollinearity on both independent variables.

Under the terms of classical assumptions of linear regression with OLS, it is a good linear regression model is free from any multicollinearity. Thus, the above model has been freed of their multicollinearity.

2. Autocorrelation

Data used to estimate a linear regression model time series data it is necessary to free the assumption of autocorrelation. In order to as certain whether the linear regression model free of autocorrelation, can use methods Brusch-Godfrey or LM (Lagrange Multiplier) Test. 
Table 3 Autocorrelation test

Breusch-Godfrey Serial Correlation LM Test:

\begin{tabular}{llll}
\hline \hline F-statistic & 0.535989 & Prob. F(2,7) & 0.6073 \\
Obs*R-squared & 1.593628 & Prob. Chi-Square(2) & 0.4508 \\
\hline \hline
\end{tabular}

Source: Output of Eviews 9, 2017

Value Prob. F $(2,7)$ amounted to 0.6073 can also be referred to as a probability value of F count. Value Prob. F count larger than the alpha level of $0.05(5 \%)$ so that, by testing hypotheses, $\mathrm{H}_{0}$ is accepted which means no autocorrelation.

3. Normality Test

Test Normality is the classical assumptions OLS approach is (data) residuals formed normally distributed linear regression model, not the independent variable or the dependent variable. Tests on the residuals are normally distributed or can't use the Jarque-Bera Test.

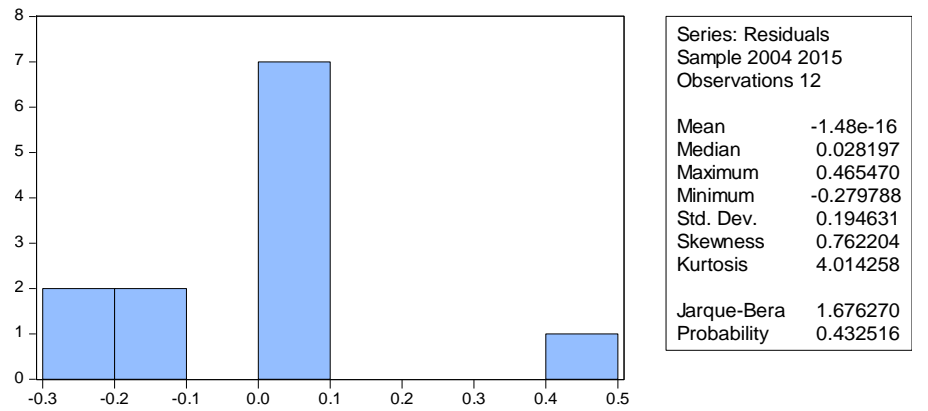

Figure 2 Jarque-Bera Test

Source: Output of Eviews 9, 2017

Decision residuals are normally distributed or not simply by comparing the value of probability JB (Jarque-Bera) is calculated with an alpha level of $0.05(5 \%)$. If Prob. JB count is greater than 0.05 , it can be concluded that the residuals are normally distributed and conversely, if the value is less then not enough evidence to suggest that the residuals are normally distributed. Value Prob. JB calculate equal to $1.676>0.05$ so that it can be concluded that the residuals are normally distributed, which means the classical assumption of normality has been met.

4. Linearity

In multiple linear regressions, testing of linearity can use the Ramsey Reset Test. Table 4 Test linearity

Ramsey RESET Test

Equation: UNTITLED

Specification: EP INFLASI PERKAPITA C

Omitted Variables: Squares of fitted values

\begin{tabular}{llcl}
\hline \hline & Value & Df & Probability \\
\cline { 2 - 4 } t-statistic & 0.366613 & 8 & 0.7234 \\
F-statistic & 0.134405 & $(1,8)$ & 0.7234 \\
Likelihood ratio & 0.199932 & 1 & 0.6548 \\
\hline \hline
\end{tabular}

Source: Output of Eviews 9, 2017 
If the value of Probability, F count larger than the alpha level of $0.05(5 \%)$ then the regression model to meet the assumptions of linearity and conversely, if the value of Prob. F count is less than 0.05 then the model can't meet the assumption of linearity. Value Prob. F count can be viewed on line F-statistic Probability column. In this study, the value 0.7234 is greater than 0.05 so that it can be concluded that the regression model has met the assumption of linearity.

5. Heterocedastisity

Heterocedastisity occur when residuals and predicted values have a correlation or relationship patterns. The pattern of this relationship is not only a linear relationship, but in a different pattern is also possible. There are several test methods of heterocedastisity that are owned by Eviews, such as: Breusch-Pagan-Godfrey, Harvey, Glejser, ARCH, White and others. This research will use Breusch-Pagan-Godfrey.

Table 5 Test Heterocedastisity

Heteroskedasticity Test: Breusch-Pagan-Godfrey

\begin{tabular}{llll}
\hline \hline F-statistic & 0.437006 & Prob. F(2,9) & 0.6590 \\
Obs*R-squared & 1.062197 & Prob. Chi-Square(2) & 0.5880 \\
Scaled explained SS & 0.900488 & Prob. Chi-Square(2) & 0.6375 \\
\hline \hline
\end{tabular}

Source: Output of Eviews 9, 2017

Decision heterocedastisity occurs whether or not the linear regression model is to look at Value Prob. F-statistic (F count). If the value of Prob. F count larger than the alpha level of $0.05(5 \%)$ means not happen heterocedastisity, whereas if the value of Prob. $F$ count is smaller than the alpha level of $0.05(5 \%)$ means going heterocedastisity. Value Prob. F calculated in this study amounted to 0.6590 is greater than the alpha level of 0.05 (5\%) means not happen heterocedastisity.

\section{a. Results and Data Analysis}

In analyzing the factors affecting the banking sharia financing in Indonesia to determine whether the financing request elasticity of Islamic banking in Indonesia is influenced by inflation and per capita income used multiple linear analysis, using ordinary least squares (OLS). The data were processed with the help of Eviews program 9. The results of the regression equation can be seen in the following table:

Table 6 Estimate Equation

\begin{tabular}{lllll}
\hline \hline Variable & Coefficient & Std. Error & t-Statistic & Prob. \\
\hline \hline INFLASI & -0.016958 & 0.023788 & -0.712903 & 0.0000 \\
PERKAPITA & -0.002858 & 0.043177 & -0.066187 & 0.0000 \\
C & 0.870899 & 0.599119 & 1.453633 & 0.1800 \\
\hline \hline R-squared & 0.688414 & Mean dependent var & 0.710833 \\
Adjusted R-squared & -0.550227 & S.D. dependent var & 0.200195 \\
S.E. of regression & 0.215173 & Akaike info criterion & -0.022432 \\
Sum squared resid & 0.416694 & Schwarz criterion & 0.098795 \\
Log likelihood & 3.134590 & Hannan-Quinn criter. & -0.067314
\end{tabular}




\begin{tabular}{llll} 
F-statistic & 0.620968 & Durbin-Watson stat & 1.215647 \\
Prob(F-statistic) & 0.000009 & \\
\hline \hline
\end{tabular}

Source: Output of Eviews 9, 2017

Based on the results of the estimation, the coefficient of determination $\left(\mathrm{R}^{2}\right)$ is 0.688414 . This means that the variable rate of inflation and income per capita together can explain the elasticity of demand for sharia banking financing in Indonesia equal to $68.84 \%$ while the rest of $31.16 \%$ can be explained by other variables not used in this research. F-statistic test aims to determine the statistical significance of regression coefficients simultaneously or collectively. Based on the results of F-statistic test in the above table, it means that all variables of inflation rate and income per capita together have a significant effect on the variable elasticity of demand for sharia banking financing in Indonesia at the level of confidence 62 percent.

The t-statistic test aims to determine the statistical significance of the partial regression coefficients. Based on the result of t-stat test of variable of inflation rate give statistically significant influence to elasticity variable of demand of financing of sharia banking at level of trust $71,3 \%$. The per capita income variable gives statistically significant influence to consumption demand credit variable in North Sumatra at 6.62 percent confidence level.

From table 4.6 it can be produced the following formula:

$$
\mathrm{Y}=0,870899-0,016958 \mathrm{X}_{1}-0,002858 \mathrm{X}_{2}
$$

\section{b. Interpretasi Model}

From the results of the above estimation can be analyzed as follows:

1. Inflation has a negative effect on the elasticity of demand for Islamic banking financing and has a coefficient of -0.016958 . This means that if inflation rises by one percent then the elasticity of Islamic banking financing will decrease by 0.016958 percent.

2. Per capita income has a negative effect on demand for Islamic banking financing and has a coefficient of 0.002858 . This means that if per capita income increased by one percent then demand for consumer credit will increase by 1.8813 percent.

\section{CONCLUSIONS AND RECOMMENDATIONS}

\subsection{Conclusions}

1. Price elasticity of demand for sharia banking financing in Indonesia fall into the category of inelastic, where if the price changed by $1 \%$ will give effect to change the amount of demand for Islamic banking financing is less than $1 \%$.

2. Together the inflation rate and income per capita significantly influence the elasticity of demand for sharia banking financing in Indonesia.

3. Based on the regression results obtained coefficient of determination (R2) of 0.688414 variable inflation rate and income per capita together to explain the variable elasticity of demand for Islamic banking financing in Indonesia amounted to $68.84 \%$ while the rest of $31.16 \%$ can be explained by variable Others not used in this study.

4. Inflation has a negative effect on the elasticity of demand for Islamic banking financing and has a coefficient of -0.016958 . This means that if inflation rises by 
one percent, the elasticity of Islamic banking financing will decrease by 0.016958 percent.

5. Per capita income has a negative effect on demand for Islamic banking financing and has a coefficient of 0.002858 . This means that if per capita income rises by one percent then demand for consumer credit will increase by 1.8813 percent.

6. Variable inflation rate and income per capita together have a significant effect on the variable elasticity of demand for sharia banking financing in Indonesia at the level of confidence 62 percent.

7. Inflation variable variables partially give statistically significant effect to the elasticity of demand for financing of sharia banking at the level of trust $71.3 \%$. The per capita income variable partially gives statistically significant effect to consumer demand credit variable in North Sumatera at a confidence level of 6.62 percent.

\subsection{Recommendations}

1. For sharia banking parties should be more promoted in other ways than by raising or lowering the price of financing when there is inflation, this is because the elasticity of Islamic banking financing prices are inelastic categories.

2. For academics there is expected to be further research to discuss the elasticity of demand for Islamic banking financing in Indonesia with different variables that have not been studied in this study.

\section{References}

Antonio, M. S. (2001). Bank Syariah dari Teori Ke Praktek. Jakarta: Gema Insani Press.

Arifin, Z. (2002). Dasar-dasar Manajemen Bank Syariah. Jakarta: Alvabet.

Attanasio, Goldberg, O. P., P. K and E. Kryiazidou, E. (2004). Credit Constraints in the Market for Consumer Durables: Evidence from Micro Data on Car Loans. Working Paper.

Ausubel, L. M. (1991). The Failure of Competition in the Credit Card Market. American Economic Review, 81 (1), 50-81

Bank Indonesia. (2009). Laporan Kebijakan Moneter Triwulan I-2009. Direktorat Riset Ekonomi dan Kebijakan Moneter, http//:www.BI.go.id.

Bank Indonesia dan Puslitbank Fakultas Ekonomi USU (2007). Intermediasi Perbankan di Propinsi Sumatera Utara: Kendala dan Solusi Penyelesaiannya. Medan.

Barro, R.J., \& X Sala-I-Martin. (1995). Economic Growth. Singapore: Mcgraw- Hill International Editions.

Gujarati, D. N. (2007). Dasar-dasar Ekonometrika (Edisi 3). Jakarta: Erlangga.

Hadad, M. D., Santoso, W., \& Alisjahbana, A. (2004). Model dan Estimasi 
Permintaan dan Penawaran Kredit Konsumsi Rumah Tangga di Indonesia.

Hall, R. E. (1988). Intertemporal Substitution in Consumption. Journal of Political Economy, 96 (1), 339-57.

Hutagalung, P. A. \& Nasution, I.G. S. (2013). Analisis Elastisitas Permintaan Terhadap Kredit Konsumsi di Sumatera Utara. Jurnal Ekonomi dan Keuangan, 1 (2), 91-104

Karlan, D., \& Zinman, J. (2005). Elastisitas Permintaan Kredit Konsumsi. Universitas Yale.

Kasmir. (2005). Bank dan Lembaga Keuangan Lain (Edisi 6). Jakarta: PT Raja Grafindo Perkasa.

Kasmir. (2005). Pemasaran Bank (Edisi 1). Jakarta: Prenada Media.

Mankiw, N.G. (2004). Teori Makro Ekonomi. Jakarta: Erlangga.

Miraza, B. H. (2006). Perjalanan Moneter dan Perbankan, Perkembangan Moneter Indonesia 2000-2005. Medan: USU press.

Mishkin, F.S. (2008). Ekonomi uang, Perbankan, dan Pasar Keuangan (Edisi 8). Jakarta: Salemba Empat.

Morduch, J. (2000). The Microfinance Schism. World Development, 28 (4): 617-629.

Muhammad. (2000). Manajemen Bank Syariah. Yogyakarta: UPP AMP YKPN.

Muhammad. (2002). Bank Syariah Analisis Kekuatan, Kelemahan, Peluang dan Ancaman. Yogyakarta: Ekonesia.

Nachrowi, D. N., \& Usman, H. (2006). Pendekatan Populer dan Praktis Ekonometrika untuk Analisis Ekonomi dan Keuangan. Jakarta: LP-FEUI.

Nasution, M. (1998). Ekonomi Moneter, Uang, dan Bank. Jakarta: Djambatan.

Nopirin. (2007). Ekonomi Moneter (Edisi 4). Yogyakarta: BPFE.

Noor, Zainulbahar. (2006). Fenomena Kebangkitan Ekonomi Islam. Jakarta: Bening Publishing

Pohan, A. (2008). Potret Kebijakan Moneter Indonesia. Jakarta: PT Raja Grafindo Persada.

Pratomo, W. A., \& Hidayat, P. (2007). Pedoman Praktis Penggunaan Eviews dalam Ekonometrika. Medan: USU Press.

Samuelson, P. A., \& Nordhaus, W. D. (2003). Ilmu Ekonomi Mikro (Edisi 17). Jakarta: PT Media Global Edukasi. 